\title{
SYLVIA TOWNSEND WARNER IN CONVERSATION
}

(The following interview with Sylvia Townsend Warner was conducted in 1975 by Val Warner and Michael Schmidt and was first published in PN Review 23, 1981. The questions were spoken off-microphone and in some cases have had to be inferred from the replies, hence an apparent terseness on the part of the interviewers. Sylvia Townsend Warner speaks first:)

I am what is that odd thing, a musicologist. I've done a lot of work on church music. I was one of the editorial committee on Tudor Church Music, which was financed, much to our surprise, by the Carnegie U.K. Trust.

Have you written music as well?

I have composed music; it's not at all good. I play the piano, and I tried to play the viola because I liked the noise. But nobody liked the noise that I got out of the viola when I was learning and so I gave it up.

You were a music scholar, but not at a university.

No, I never went to a university. I never went to school ... well, I went to kindergarten for about two terms, and then I was dismissed for being a bad influence. I was a natural mimic, and I mimicked the unfortunate people who were teaching me. I didn't mean any wickedness by it, but like Mary's lamb, I made the children laugh and play and was a 
very bad influence. They sent me back with a very dubious report; only one kind word in it and that was, 'Sylvia always sings in tune.' That sort of thing decides one's destiny, of course.

I left home when I was twenty-two and went to London. By that time I'd got my job on the Tudor Church Music Committee. I made a living from that-rather a penurious living to begin with. I got $£ 130$ a year from the United Kingdom Trust and it annoyed me very much because the money came from Scotland and was paid monthly and it seemed to me wasteful to have to pay sixpence on a Scotch cheque once a month. I could barely afford it, so I wrote to their treasurer and said that it was very inconvenient and could he change his arrangements and pay me once a quarter. After that, I think he felt I was serious.

\section{And it was about that time you began writing poetry?}

When did I begin to write? I was led away by paper. I'm always led away by blank paper. We had a great many photographs in our work, black and white photographs of manuscripts, and there were always some throw-aways. And the white was the most beautiful smooth white photographic paper and nobody wanted it, and I wanted it, and having collected it by degrees I thought, 'I must do something about all this handsome paper-I think I'll write a poem.' So I started writing poems on this handsome paper.

My first book was The Espalier, and that came out in, I think, 1925. After Chatto \& Windus had seen my poems (they were sent there by David Garnett who liked them) and they said tentatively, 'You don't think you could write a novel, do you?' and I, with exasperating brightness, said, 'I've written a novel, but it isn't worth anything. I only did it to amuse myself in the evenings when I had nothing better to do.' And that was Lolly Willowes. And except that Charles Prentice wanted me to rewrite the ending, I didn't get to alter it much. I could have altered it more.

I never thought of being a professional writer. I never thought of being a professional anything, to tell the truth. I 
just slopped along like Mrs Warcornisher's English Lady, you know, doing one thing at one time and another at another.

\section{When did your political activities begin?}

I'm trying to remember. I think it was in $1933 . .$. I know what influenced me and what influenced almost all the people of my generation more than anything was the Reichstag Fire trial. Extraordinary courage and enterprise and poise of Dimitrov. And that was very well reported in The Times and made me interested in contemporary politics. And that of course made me immediately interested in the doings of the Black Shirts, and that's how I came to meet the people in Left Review and eventually to do some writing. That's how I met Edgell [Rickword].

The Left Review I should say began about 1934. We went to Spain in 1936, to Barcelona. We had the greatest difficulty in getting across the frontier but everything went smoothly after that. And then the next year, with Valentine Ackland, I went to the Congress of anti-Fascist writers which had been scheduled to be held in Madrid before the war broke out, but in 1937 they still held the Congress; and a very fine Congress it was.

I wrote a few articles about life in wartime Spain and got them in where I could simply as propaganda. And of course by that time it was getting rather hard to get in any propaganda because the English authorities and respectables were clamping down on freelance journalists who had anything to say in favour of the Republic. I had a great deal to say. . . . I've never seen people who I admired more. I never again saw a country I loved as much as I loved Spain. A most ungainly country to love, but it is extraordinarily beautiful. I've never been back-I said I wouldn't go back till Franco was dead and the old brute is still hanging on.

The experience affected my writing to the extent that I wrote After the Death of Don Juan, which is definitely a political novel-at least perhaps I should say it's a political fable. It's very rare to get now, but I think it's an extremely 
good story because I took the Mozart subject as my framework but continued it into the Spain of this day and age. The trouble was it was published in 1938 and in not a very large edition and was soon swamped in the circumstances of the time.

Would you describe yourself as a Communist or an anarchist?

I was a Communist, but I always find anarchists very easy to get on with. I think that's because, if the English turn to the left at all, they are natural anarchists. They are not orderly enough to be good Communists and they're too refractory to be good Communists. I became a Communist simply because I was agin the Government but that of course is not a suitable frame of mind for a Communist for very long. But you can go on being an anarchist for the rest of your life, as far as I can see, and doing very well. You've always got something to be anarchic about-your life is one long excitement. And anarchists are the most charming people!

Summer Will Show is very much a political novel too.

That sounds communist, but I think at that date for anybody of intelligence, that was the only way for them to go. When I wrote that book I had the most interesting time because I thought I ought to do a little research and so I poked up from the London Library books about that date written from the Orleanist point of view and then the Monarchist point of view, and the Socialist point of view and then casual memoirs, and nothing agreed with anything else.

Did your political commitments affect the reception of your work?

Oh, it affected it very badly. I usually had two or three amazingly good reviews, but I never had reviews from the sort of reviewers that sell books. I've never produced a bestseller. I sell very well to The New Yorker, that's my only claim to being a bestseller. They were providential. I began writing for them as the result of a dare because we had an American friend staying with us and I was telling her of some 
absurd thing which had happened in the village and she said, 'You really ought to write that for The New Yorker.' I said, 'Ba Pooh! I can't write for The New Yorker. People who write for The New Yorker are a special race-they are like nothing else. I couldn't write for The New Yorker!' And she said, 'Oh write it; I think they'd take it.' I said, 'Bet you they wouldn't!' She said, 'Well, try it!' I said, 'I bet you $£ 5$ that they won't take it.' And they did, so I had to forfeit the $£ 5$. But on the whole, it was a good bargain.

I'm now concentrating on an entirely different new kind of short story and have been for the last three years because I suddenly looked round on my career and thought, 'Good God, I've been understanding the human heart for all these decades. Bother the human heart, I'm tired of the human heart. I'm tired of the human race. I want to write about something entirely different.' And my first story in my new vein was called 'Something Entirely Different'. It was a study of the problems of changelings. It was about a human child that was taken into Elfinland and what became of him, and also what became of the elfin child who was planted in the human child's cradle and had to grow up in a small Scotch village. I found that so engrossing and I kept on making the most delightful discoveries of great social importance. I discovered that no well-bred fairy would ever dream of flying; they leave that to the servants. When one has discovered some truth of that sort, it's so reviving, it's such fun. And I don't want to write a respectable, realistic story ever again!

But of course there was a great deal of fantasy in your novels too, in Lolly Willowes for example.

Yes, it put its ugly face out in Lolly Willowes, didn't it? I think that I've always been interested in the supernatural in its social aspects, partly reading Pitcairn's Law Trials of Scotland. It's by far the best record of the activities of witches and witch hunters in Scotland and written in the most beautiful Scotch and I enjoyed reading that. And I suppose I went on from there. Of course I was very much influenced 
by old Margaret Murray's book, The God of the Witches. She was a surprising old lady-looked exactly like Queen Victoria.

Of your novels and poetry, which has taken precedence, and which would you say is most important?

By now, I suppose, my novels. The Corner That Held Them took a long time to write and that was an important book in my life. I wrote it all through the war at intervals of all the other horrible things I had to do and whenever I got a moment to myself I went on with that.

I think that it is my most personal book, probably, and I believe that After the Death of Don Juan was my next most personal, though it appears to be quite impersonal because it's written with an arid degree of satire.

\section{Would you call yourself a Christian?}

Oh no! I couldn't possibly do that. I couldn't do that to anyone! No, I've never had any temptations to be a Christian. I think partly because of the Christians I met as a child. There was a dreadful old woman who was the family nurse in a family I knew, and having studied her all through one joint holidays I said to my mother in confidence, 'Are all Christians cross?' She replied, with great justice, 'Not all of them.'

In The Corner That Held Them I had to include religion, but then I began that book on the purist Marxian principles because I was convinced that if you were going to give an accurate picture of the monastic life, you'd have to put in all their finances, how they made their money, how they dodged about from one thing to another and how very precarious it all was, how only the very rich orders had any sort of financial security. The small houses just dodged about on the edge of the abyss; they were nearly always bankrupt. That's why the monastic houses were dissolved in Englandthey were all bankrupt, except just three or four and they were so rich that everyone wanted their money. But it's a strictly capitalist story. 
What about your poems? You published a volume of poems with Valentine Ackland, called Whether a Dove or Seagull, in which none of the poems is attributed to either writer, saying in the foreword that too much importance was attached to the poet rather than to the poem. Was that a successful gesture?

That was because I'd seen so many people snaffling through anthologies, picking out poems by the poet they liked without ever troubling to read the others. I think it was a vain gesture; I think people still read by the name of the author rather than by the contents of the work.

And you published a volume of poems to accompany engravings, too.

Yes, Boxwood. That was a ridiculous affair because Reynolds Stone was a friend of mine and we'd gone to visit him one day and found him sitting on the floor in an attitude of despair, tossing over anthologies. It developed that Ruari Maclean wanted to do a collection of his woodcuts and thought it would be child's play for Reynolds to find suitable quotations to 'illustrate' the woodcuts. Poor Reynolds was going out of his mind looking for suitable quotations and I thought to myself that it was far more important for him to go on with his woodcuts than to be hunting out quotations and I said to him, 'Leave all this nonsense. I'll write you poems to illustrate your drawings; I can do it in half the time! And that's what they were.

What about form? In the poems especially, you keep to very strict forms, by and large...

Well, that's a different strand. I keep to a formal mode. I'm extremely fidgety about form, but that was because of music. I really learned all my ideas of form from studying music. I think there's something to be said for the formal shape if you've learned how to manage it and if you've got something to say. Really I believe that the thing that forms the structure of any narrative and holds it together is the importance of the narrative, the interest one has in the 
narrative. That's why Defoe is such a master, because he's really interested in the story.

Isn't there some incompatibility between political anarchism and formalism in writing?

I dare say there is. I remember a passage in Walt Whitman where someone or other is accusing him of being inconsistent and he says, 'Am I inconsistent? Well, I am inconsistent. Within me I contain millions!'

I'm more at home with seventeenth-century poetry than with any other. I'm a very great admirer of Dryden, because Dryden can say anything. He makes the most ridiculous statements and he can always bring them off. The line in 'The Hind and the Panther' that I particularly like-it's the last line of a section: 'The Lady of the spotted-muff began'. Now that is a line which is purely nonsensical and yet Dryden is so stately in his control of the medium and so sublime that one hears it almost with awe. When that line comes, one is merely delighted: Here is a splendid line.

Dryden has much more meat to him than Pope. I'm always attached to Marvell. I'm devoted to Defoe, and I'm fairly well at home with the Russians. I was very lucky: my mother liked reading aloud and she only read aloud the books which she liked herself and so it was that I heard the whole of War and Peace read to me before I was fourteen. Thackeray doesn't stand up to time so well. My passion for Flaubert and Stendhal, particularly for Stendhal, has never wavered. Stendhal is a very interesting Romantic because he's satirical. He's being intensely Romantic with half of him and there's a small cold beady eye which is fixed on the Romantic Stendhal saying, 'My God! What antics will this man get up to next?' I like inconsistencies in authors; I think I like inconsistencies in any creative work.

At the moment, I think the novel is falling to pieces, but I don't know how it will pull itself together again. Of course, it may be a varying form. It's been around for a very long time. I'm quite sure that the biography is an up-and-coming form, that much more in the way of biography will happen, 
partly because there's such a demand for it. Think how people seized on Boswell when Boswell's Diaries were put out.

You've written a biography of T.H. White, a writer who admired your work.

That was a queer assignment, because I didn't know White, although I knew various friends of his and I think we had occasionally exchanged polite letters praising each other's books. And then White made a demented departure because he never made a will and he never appointed a literary executor. He left all his manuscripts of his unfinished books to the Bank of Alderney, which poor creature hadn't the least idea what to do with them. His literary agent, a good worthy man, but a fool, was very anxious to get a great deal of White published and wanted to have a biography of White and naturally wanted to write it himself. White's friends were appalled at the prospect because they didn't think he'd do it very well, and after a great deal of consultation and tossing to and fro, they asked me if I would like to take it on and I said I didn't think so. But I was led astray because Michael Howard turned up in a very large car, most of which consisted of boot, and he opened up the boot and out came so many pages, hunks of typescript, hunks of unfinished books, and I was told that this would be some of the material, but of course there would be a great deal more. And when it had filled a whole room in my house I thought, well the only way to get rid of all this is to read it and do the book! By that time, I was beginning to find White rather interesting. He's an inconsistent character. He could never finish anything, that was the trouble about him.

\section{What are you working on at the moment?}

I'm working on those short stories. I'm not working on anything else. And I'm steadily refusing to write an autobiography.

\section{Why's that?}

Because I'm too imaginative. 
Do you still write poems?

Oh yes, usually just when I'm about to pack or catch a train or have someone to stay. Always at inconvenient moments like that. And I revise them endlessly, endlessly. I revise everything that I do. 